\title{
The Relationship Between Migraine and Nutrition
} Migren ve Beslenme İlişkisi

\author{
Ayçıl Özturan 1 , Nevin Şanlıer ${ }^{1}$, Özlem Coşkun² \\ ${ }^{1}$ Gazi University Faculty of Health Science, Division of Nutrition and Dietetics, Ankara, Turkey \\ ${ }^{2}$ Gazi University Faculty of Medicine, Department of Neurology, Ankara, Turkey
}

\section{Summary}

Migraine is a kind of headache accompanied by neurologic, gastrointestinal, and autonomous variations. The roles of factors that trigger migraine, especially nutrition triggers, have become much more questionable with the increase in the rate of migraine occurrence. Some patients with migraine have stated that their headache attacks start without any reason. However, inner triggers such as hormonal changes or external triggers such as air exchange, some smells or the association of both triggers can start the headache. Each patient may not have same sensitivity to these triggers. A single factor might become prominent in some patients, but more than one factor may need to be required in other patients. Although the connection between migraine and the factors such as stress, environmental factors, chronic diseases, and nutritional and sleep status has been known, their mechanisms are still not clear. Nutritional status and the effects of nutrition play an important role being pain triggers in everybody, especially children and young people who suffer from migraine headache. Considering the migraine triggers generally, it has been suggested in studies that there is at least one nutrition-related trigger and hunger is the most frequently reported trigger in terms of diet. Moreover it is known that chocolate, tea, coffee, cheese, and alcohol may trigger migraine because of some specific elements within them. In recently conducted studies, using some functional foods have raised on the treatment of migraine. For this reason, the relationship between migraine and triggering factors as food and nutrition are examined in this study.

Keywords: Migraine disorders, food, nutritional status

\section{$\ddot{O} \mathbf{z}$}

Migren, binlerce yıldan beri bilinen bir hastalık olup nörolojik, gastrointestinal ve otonom değişikliklerin eşlik ettiği bir baş ağrısıdır. Migrenin görülme sıklığının artmasıyla birlikte migren tetikleyici faktörlerin rolü ve özellikle tetikleyici besinler daha fazla tartışılır hale gelmiştir. Bazı migrenli hastalar baş ağrısı ataklarının nedensiz bir şekilde başladığını ifade etmektedirler. Ancak çoğunlukla hormonal değişimler gibi içsel ya da hava değişimi, bazı kokular vs. gibi bir dışsal tetikleyici ya da tetikleyicilerin birlikteliğgi ağrıyı başlatabilmektedir. Her hasta bu tetikleyicilere karşı aynı duyarlılıkta olmayabilir. Bazılarında tek bir faktör öne çıkarken, bazılarında da birkaç faktörü birden ele almak gerekebilmektedir. Stres, çevresel faktörler, kronik hastalıklar, uyku ve beslenme durumu gibi etkenlerin migren ile ilişkisi bilinmekle birlikte bu etkenlerin mekanizmaları hala net değildir. Çocuklar ve gençler başta olmak üzere migren tipi baş ağrısı çeken herkeste ağrıyı tetikleyici olarak beslenme durumu ve besinlerin etkisi önemli yer tutmaktadır. Genel olarak migren tetikleyicileri düşünüldüğünde yapılan çalışmalarda en az bir beslenme kaynaklı tetikleyici öne sürülmekte, diyet açısından en sık bildirilen tetikleyicinin açlık olduğu söylenmektedir. Çikolata, çay, kahve, peynir, alkolün ise içerdiğgi bazı spesifik öğeler sebebiyle migrende tetikleyici özellik gösterdiği belirtilmektedir. Yapılan yeni çalışmalarda migren tedavisinde ek olarak bazı fonksiyonel besinlerin kullanımı da gündeme gelmiştir. Bu nedenle, çalışmada migrenin tetikleyici faktörlerinden besin ve beslenme ile ilişkisi irdelenmiştir.

Anahtar Kelimeler: Migren hastalıkları, besin, beslenme durumu

Address for Correspondence/Yazışma Adresi: Nevin Şanlıer MD, Gazi University Faculty of Health Science, Division of Nutrition and Dietetics, Ankara, Turkey Phone: +903122162601 E-mail: nevintekgul@gmail.com

Received/Geliş Tarihi: 25.01.2015 Accepted/Kabul Tarihi: 11.02.2016 


\section{Introduction}

Migraine is a primary, episodic disorder in which different combinations of neurologic, gastrointestinal, and autonomic alterations accompany (1). Migraine affects 240 million people worldwide who are affected by approximately 1.4 billion migraine attacks each year (2). Migraine frequency in women is known to be twice that of men during the menstrual period and migraine attacks are more severe (3); a study from İstanbul detected the beginning age of migraine in women to be 22.7 years (4). Migraine is not a single symptom or a problem that occurs at a single location. Also, it does not always present with a similar pattern, instead it may sometimes be progressive (5) and it is diagnosed based on patient's history. Causative factors should be considered for the first headache but migraine classifications should be considered when pain becomes chronic (6). Typical features of migraine are headache that may last for 4-72 hours, generally unilateral, which may be moderate or severe in severity and tends to recur. Its severity generally increases with physical activity, nausea, and sensitivity against light and noise occur $(7,8)$. A study found the most common symptoms were noise sensitivity $(91.3 \%)$ and nausea $(74.8 \%)$. The same study also investigated triggers and found that stress $(81 \%)$ and noise $(54.5 \%)$ were the most frequent triggers although hunger $(37.2 \%)$ and certain foods $(5.9 \%)$ were also among the triggers (4). There is a complex relationship between migraine and nutrition. Food can affect nervous pathways, which produces pain through the vasoconstrictor or vasodilator properties of their ingredients $(9,10)$. Although there are acute and preventive treatments for migraine, nutrition still seems to be an important component. For the evaluation of migraine patients, food consumption is investigated and the patient is asked to keep a migraine diary to identify food that caused the attack. Studies revealed at least one trigger stemming from nutrition and the common triggers were skipping meal, caffeine, dairy products, alcoholic beverages, fermented food, and chocolate $(9,11)$. Fasting is generally seen as an important trigger and alcohol intake is important, especially for younger patients $(9,12)$. Cheese, chocolate and red wine that include these chemicals are also important triggers of migraine because tyramine, phenylethylamine, and histamine are believed to play roles in the mechanisms that trigger headache (13). In recent years, functional nutrients are believed to be effective in the prevention and treatment of migraine. Although studies are limited, magnesium, riboflavin, coenzyme Q, coltsfoot and chrysanthemum are known to have beneficial effects $(11,14)$. Magnesium and chrysanthemum affect serotonin receptor activity, coenzyme $\mathrm{Q}$ and riboflavin affect oxidative metabolism, and coltsfoot have anti-inflammatory effects and therefore they play roles in migraine development (14). Additionally, although elimination diets are recommended in migraine treatment and the effects of this treatment are known to be based on the migraine triggering effect of food allergy, the role of mechanisms associated with immunoglobulin ( $\mathrm{Ig}$ ) $\operatorname{IgE}$ and $\operatorname{IgG}$ are still controversial $(10,15)$.

\section{Trigger Factors}

Some patients with migraine patients state that their headaches begin without any apparent cause. However, in most occasions, endogenous factors such as hormonal changes and exogenous changes such as weather factors or some odors may initiate headaches. Every migraine patient may not be at same sensitivity level to these factors. A single trigger may initiate pain in some of these patients but several factors are needed to initiate pain in others. Migraine is frequently triggered by stress, menstruation, insufficient or excessive sleep, weather changes (humidity, wind, atmospheric pressure), missing a meal, alcohol (especially wine and beer), odor (perfume or chemical with sharp odors), bright lights, cigarette smoke, high altitude, cough, or some food (16). The most common food triggers are alcohol, chocolate, cheese, caffeine, monosodium glutamate, and aspartame (11). In addition to environmental factors, personal problems or chronic diseases, premenstrual syndrome, pregnancy, hypertension, or obesity may be causes or triggers of pain $(17,18,19,20)$. A study in patients with and without aura $(\mathrm{n}=182)$ detected stress $(94.5 \%)$, meal skipping $(89 \%)$, noise $(87.9 \%)$, insufficient sleep period $(87.4 \%)$, fatigue $(86.3 \%)$, bright light $(79.1 \%)$, menstruation $(77.3 \%)$, sharp odor (69.2\%), and weather conditions $(65.4 \%)$ were detected to triggered migraine and food triggers were found to be the cause in $79.1 \%$ of the patients. In addition, this study suggested that females were more sensitive to food triggers. The brain regions affected by migraine triggers may vary between the sexes because of differences in neurotransmitter concentrations, receptor sensitivity, or hormonal interactions (21).

\section{Migraine in the Presence of Insulin Resistance and Obesity}

Insulin sensitivity is known to be impaired and diseases such as hypertension, diabetes, high cholesterol, and obesity are commonly seen in patients with chronic migraine patient. The highest migraine prevalence was found in morbidly obese women $(17,20)$. The association between migraine and obesity has received much attention over the last 10 years. A study evaluated patients who had different types of headache by dividing them into 5 groups according to body mass index (BMI) (lean, normal, overweight, obese, morbidly obese). Study results showed that although migraine prevalence was not affected by BMI, the risk of chronicity of episodic migraine was higher in migraine patients who were obese (20). The first longitudinal study about headache-obesity relationship monitored 1192 patients with episodic headaches or chronic daily headache aged between 18-65 years for 11 months. The transformation of episodic headache to chronic daily headache was found 5 times higher in obese patients compared with non-obese patients (22). Another study found that risk of headache in obese patients compared with patients with normal BMI was $35 \%$ higher and $80 \%$ higher in morbidly obese patients (23). Additionally, daily headache was associated with obesity and obesity was a stronger risk factor for migraine than tension type headache (20). Obese patients were reported to have $47 \%$ more headache or migraine than non-obese patients among 14000 young women aged between 18-23 years (24). A study of 30215 subjects found migraine symptoms in 3791; there was no association between migraine prevalence and increased BMI but an association was found between increased body weight with increased headache incidence and pain severity (25). A recent study in similar age groups found a relationship between migraine and 
obesity $(26,27)$. Several adipocytokines are released from adipose tissue. Adiponectin is one of the adipocytokines. Adipokines have inflammatory properties and they may aggravate inflammatory disorders. A study on this topic in female patiens with migraine evaluated adiponectin and oligomer levels before and after an unsuccessful acute treatment; adipokine levels significantly decreased after treatment and this suggested an association between adipokines and migraine (28). However, the relationship between migraine and obesity and the role of adipokines in this relation is still far from exact. Leptin is an adipocyte hormone that is an important regulator of food intake and energy homeostasis. Regulated leptin levels help to prevent obesity. The leptin levels of 61 patients with episodic migraine and 64 controls were not different between patients with migraine and controls according to BMI. Adipose tissue mass and percentage were significantly lower in patients with migraine. In conclusion, low leptin levels and adipose tissue mass were related with migraine pathogenesis (29). Although studies about the relationship between metabolic syndrome and migraine are limited, 11.3 years of follow-up of 19895 subjects showed an association between migraine and increased risk of metabolic syndrome (30). Gozke et al. (31) investigated the association between tension-type headache and migraine with metabolic syndrome parameters and concluded that patients should be monitored for hypertension and hyperlipidemia especially, but no data were found to support a higher presence of metabolic syndrome in different types of headache. Another study in 210 patients with metabolic syndrome showed that migraine accompanied the metabolic syndrome in $19.5 \%$ of the patients. The results of the study demonstrated that increased waist circumference, obesity, and impaired glucose metabolism, which are components of metabolic syndrome, were more frequent in patients with migraine. Insulin resistance was suggested to be responsible for high migraine prevalence because it is common in the pathogenesis of these disorders (32). A study evaluated 83 patients with episodic migraine patients, 83 patients with chronic migraine, and 83 healthy individuals, and BMI, waist circumference, and blood pressure measurements were performed. In addition, fasting glucose, 2-hour oral glucose tolerance test with $75 \mathrm{~g}$ glucose, serum HbA1c, blood lipid profile, C-reactive protein, and prolactin levels were measured. There was a significant association between insulin resistance and migraine and the patients with chronic migraine patients had 3 times more insulin resistance compared with patients with episodic migraine. However, considering migraine risk, the comorbidity of obesity and insulin resistance was riskier than insulin resistance alone (17). In recent years, several orexigenic and anorexigenic peptides that are released from hypothalamus have been believed to have roles in the pathogenesis of migraine and obesity. Hypothalamic symptoms such as increased appetite, disturbance in mood and sleep, and postdromal symptoms in migraine were associated with this condition. Also hypothalamic disturbance may cause hyperphagia and increased body weight. In addition, hypothalamic peptides and nutrition-related neurotransmitters such as orexin and adipokines may contribute to the pathophysiology of migraine. Regulation of the release of these peptides and proteins may trigger or contribute to the development of headache in migraine (26).

\section{Association with Nutrition}

\section{Food Triggers}

Nutrition and food status are very important triggers of pain especially in children and adolescents (9). Fasting, alcohol, chocolate, and cheese are the most commonly reported triggers (Table 1) (10). Generally, at least one nutritional trigger is found in studies that evaluated migraine triggers and the most commonly reported trigger was fasting, followed by chocolate and alcohol (12) alcohol intake is a potential cause of recurrent headache in teenagers (9). Patients with migraine may sometimes be very sensitive to one or more food components and this may be associated with food intolerance. A skin test for food allergy is a commonly used method to test for intolerance. The main chemicals that were proposed to trigger headache include monosodium glutamate, nitrate, nitrite, tyramine, phenylethylamine, and other amines including histamine. Tyramine is found especially in cheese like cheddar, phenylethylamine is found in chocolate, octopamine is found in citrus fruits, and histamine is found in red wine and beer. Caffeine dependence and excessive coffee consumption are also associated with throbbing headache and migraine. Fasting and missing meals may also be factors that cause relapse of pain in patients with migraine $(11,13)$. Alcohol consumption may not be tolerated in some patients with headache and it may be an important trigger; therefore, patients are recommended to avoid alcohol (33). Sodium nitrite, which is generally used for food coloring and prevention of botulism may cause headache in some patients and this effect may be due to nitric oxide release and the resulting vasodilatation. Therefore, subjects who are sensitive to these nutrients are recommended to avoid them (11).

Food triggers may exert their effects by mediating serotonin and norepinephrine release, causing vasoconstriction or by directly stimulating brain-stem and cortical nervous pathways. In this case treatment can be initiated by omitting food triggers from the diet (9).

\section{Alcohol}

Although alcoholic beverages are known to trigger headache, the type of beverage is also important for the development of pain $(8,34,35)$. Although not exactly known the mechanism through which alcohol triggers migraine may be associated with ethanol, biogenic amines (histamine, tyramine, phenylethylamine, or others), sulfides, phenolic flavonoids, serotonin release from thrombocytes, or dehydration $(33,34)$. Red wine in particular is

Table 1 . The most commonly reported nutritional triggers (10)

Chocolate
Citrus fruits
Diary products (yoghurt, cheese)
Fatty and fried food
Tea, coffee, cola
Aspartame
Alcoholic beverages
Food colorings


shown as an example for triggering migraine among alcoholic beverages even individuals without migraine may develop headache after red wine consumption. Mechanism is believed to be associated with phenolic flavonoid radicals and tannin but because white wine may be even more effective in development of headache than red wine a consensus cannot be reached over red wine $(33,35)$. On the other hand, red wine, whisky, and darkcolored alcoholic beverages are natural by products of alcoholic fermentation and include same-type substances. They cause more morning headaches when compared with clear alcoholic beverages like gin or vodka (11). An association has been proposed between alcohol and migraine. Therefore, due to the trigger effects of some of its ingredients red wine should not be consumed by patients with migraine.

\section{Chocolate}

Chocolate is believed to induce migraine because of its ingredients like theobromine, caffeine, and biogenic amines such as phenylethylamine $(34,36)$. Twenty percent of the patients in a study considered chocolate to be a headache trigger (34). However, a study on 63 women with chronic headache found that chocolate had no migraine or headache triggering effect (37). The effect of chocolate can be better understood with a diet diary because studies on migraine and chocolate may give conflicting results. Individuals whose headaches are believed to be triggered by chocolate may limit its use or totally avoid it.

\section{Cheese}

Cheese has been suggested to induce migraine because it includes biogenic amines especially tyramine $(13,34)$. An evaluation of nutrients that trigger migraine revealed that $0-19 \%$ of patients reported that cheese triggered their migraine or headache attacks (34). Although biogenic amines inside cheese are considered separately among migraine inducers, cheese consumption should also be limited because there are reports that relate cheese consumption with migraine attacks.

\section{Biogenic Amines}

Biogenic amines like histamine, tyramine, phenylethylamine, putrescine, cadaverine, and spermidine which are found in several foods play important roles in human metabolism. Histamine, tyramine, and phenylethylamine are especially associated with migraine and headache (36). Intravascular and subcutaneous administration and inhalation of histamine were shown to cause headache. However there are insufficient studies to support this hypothesis (7). A study on patients with cluster-type headache and migraine found increased plasma levels of biogenic amines (especially tyramine, octopamine, and synephrine). Therefore, more research is warranted to determine the role of biogenic amines in headache (38). Although some biogenic amines have been associated with headache, no studies to date have provided an evidence base.

\section{Table 2. Effects of functional nutrients on migraine (14)}

\begin{tabular}{|c|c|}
\hline Functional nutrients & Effect on migraine \\
\hline Magnesium & $\begin{array}{l}\text { Neuro-inflammatory blockage } \\
\text { Calcium channel blocking effect } \\
\text { NMDA receptor blockage, NO synthesis, release and activity } \\
\text { Serotonin receptor affinity and activity } \\
\text { Endogenous hormone regulation plays role in vascular and neural processes }\end{array}$ \\
\hline Riboflavin & $\begin{array}{l}\text { Riboflavin is important because it is a major cofactor in oxidative metabolism and mitochondrial energy } \\
\text { production. Riboflavin metabolism in the brain may affect migraine pathophysiology through several } \\
\text { mechanisms } \\
\text { Migraine was defined as a defect in oxidative metabolism in the brain. Mitochondrial dysfunction in } \\
\text { migraine is related with low mitochondrial riboflavin levels and it has a potential role in increasing } \\
\text { mitochondrial energy productivity } \\
\text { Riboflavin is known to have important roles in controlling cardiovascular risk in patients with migraine } \\
\text { with aura }\end{array}$ \\
\hline Butterbur & $\begin{array}{l}\text { Butterbur, is believed to have analgesic effects by causing anti-inflammatory inhibition of leukotriene } \\
\text { biosynthesis and also regulates calcium channels. Both actions are important for their effect on migraine }\end{array}$ \\
\hline $\begin{array}{l}\text { Chrysanthemum } \\
\text { (feverfew) }\end{array}$ & $\begin{array}{l}\text { Chrysanthemum (feverfew) probably exerts its anti-migraine effects by its bioactive ingredient } \\
\text { sesquiterpene, which is parthenolide lactone and has a lactone structure. In addition, chrysanthemum } \\
\text { also includes melatonin which casts doubt on whether the parthenolide is its major active ingredient. } \\
\text { Parthenolides are known to inhibit prostaglandins that transmit pain, inhibit serotonin which induces } \\
\text { migraine, and decreases platelet production in capillaries }\end{array}$ \\
\hline
\end{tabular}




\section{Caffeine}

Caffeine is commonly found in chocolate, tea, coffee and cola which are parts of our everyday diet. Caffeine causes vasoconstriction and release of stimulating neurotransmitters and stimulates adenosine receptors inside the brain and vessels and blocks their inhibitors (11). A study in young adults and adolescents who had excessive amounts of tea and coffee intake showed an association between coffee consumption and migraine (8). In addition, in the $2^{\text {nd }}$ edition of the International Classification of Headache Disorders 2 (item; 8.4.1) if caffeine intake in 2 weeks is equal to or more than $200 \mathrm{mg}$, abrupt cessation of caffeine may also have a triggering effect (39). Caffeine may be important in headache mechanisms because it is known for its stimulating effects. The exact amount of caffeine that can be associated with headache is not known because these studies generally assess caffeine amount by tea and coffee consumption.

\section{Aspartame}

Aspartame is an artificial sweetener that is 150-200 times sweeter than sucrose. Symptoms associated with aspartame use include neurologic symptoms and migraine. Although migraine induction by aspartame is not certain, $30 \mathrm{mg} / \mathrm{kg}$ aspartame intake is the normal daily dosage, and harmful effects are seen when intake reaches $75 \mathrm{mg} / \mathrm{kg}$ (34). It is not possible to reach firm conclusions about the mechanism of action and risk level with aspartame because too few studies have assessed the relationship between aspartame and headache; more research is warranted on this topic.

\section{Fasting}

Missing a meal or fasting are common triggers of migraine in adults (8). Hypoglycemia that accompanies migraine has been suggested to induce migraine. More frequent and smaller meals, and snacks may be suggested as a strategy to prevent headache because such an approach regulates glucose levels. Regular meal times also improve hypoglycemia and may be suggested as a factor in migraine treatment. Although glucose levels have not been evaluated in patients with migraine, nourishment may have a protective effect against headache (40). Although definite results have not been obtained to confirm that fasting-induced hypoglycemia attacks induce migraine this should also be kept in mind. For this reason, snacks should be planned within the diet of patients with migraine; patients should not be without food for long hours.

\section{Functional Nutrients}

Functional nutrients are defined as foods that have health benefits that are used to prevent or treat diseases. The main nutrients used for migraine treatment are shown in Table 2 (14). Although there few studies about the association of functional nutrients with migraine, important results have been obtained. Functional nutrients should be diversified and more research should be performed on this topic.

\section{Lifestyle Arrangements}

\section{Preventive Treatment}

Although $25 \%$ of patients with migraine believe that prevention is necessary, preventive treatment is used by very few patients (1). Pharmacologic treatment of migraine may be acute to terminate the attack or preventive to protect against the attack. Although preventive treatment is appropriate for many patients with migraine, a decision should be made with consideration of vocational productivity, and social, familial and recreational activities $(1,41)$.

\section{Magnesium Supplementation}

Magnesium is the second intracellular cation that is important in many intracellular processes and it plays a very important role in migraine pathogenesis. Magnesium deficiency plays important roles in cortical spreading depression, platelet hyper aggregation, serotonin receptor function, and release of certain neurotransmitters. Magnesium deficiency may develop in patients with migraine due to a genetic defect in magnesium reabsorption, magnesium loss from kidneys, emptying of magnesium stocks due to stress, low dietary intake, or some other reasons. The daily recommendation for magnesium is $400 \mathrm{mg}$ magnesium oxide. If this treatment does not produce the desired effect, dose can be doubled (42).

\section{Nutritional Treatment}

Considering migraine to be associated with allergy elimination diets that removed allergic food from the diet were considered. The relationship between migraine and allergy was first proposed by Lesne and Richet in 1913 and migraine was considered an atopic disease for many years. Although many reports have demonstrated that migraine attacks developed due to food allergy, the role of the interaction between migraine and allergy and the role of $\mathrm{IgE}$ mediated allergic mechanisms in pain production are still debated (15). IgE should be considered when considering elimination diets for patients with migraine based on food allergy; specific diets have been shown to reduce migraine attacks. However, the IgG response generally develops more slowly (10). A study that assessed the effectiveness of elimination diets in 30 patients with migraine without aura reported a significant decrease in the number of migraine attacks and days with headache. In this study elimination diets were determined based on IgG antibodies and mainly spices, dried nuts, seafood, starch, and additives were detected to produce IgG-positive responses (43). A study on patients with irritable bowel syndrome and migraine evaluated the effectiveness of elimination diets; the authors reported a decrease in number and duration of attacks and symptoms. This study also evaluated nutrients that produced an IgG response and listed dry fruits, cereals, spices, and several fruits and vegetables (44). Another frequently studied topic has been consumption of functional nutrients. A study that evaluated the association of functional nutrients and other nutrient groups and reported that $400 \mathrm{mg}$ magnesium, butterbur $75 \mathrm{mg}$ twice a day for a month and then $50 \mathrm{mg}$ a day, chrysanthemum $100 \mathrm{mg}$ a day, coenzyme Q10 $300 \mathrm{mg}$ a day, riboflavin $400 \mathrm{mg}$ a day, and alpha lipoic acid 600 mg a day may be given (11). Balanced, regulated and diversified food is recommended during pregnancy, which is a risky period for migraine development due to hormonal effects. Fasting and hypoglycemia should be avoided. Limiting chocolate, cheese, and monosodium glutamate intake may help to decrease headaches but due to the benefits of cheese, its limitation during pregnancy may not be appropriate. On the other hand, limitation of alcohol intake and cessation of smoking are also recommended for health reasons. Patients should also try to avoid stressful conditions. Relaxation 
techniques such as breathing exercises also play important roles (45).

\section{Conclusion}

In conclusion migraine is known to be a severe neurologic disorder that affects the social lives of individuals. New approaches are being developed for the treatment of migraine which is associated with many variables such as lifestyle, food choice, specific problems of individuals and chronic illnesses. Nutritional regulation forms an important part of environmental and individual factors. Therefore, patients' avoidance of drug use has popularized the use of functional nutrients, and more research on this topic is needed. Use of a diet diary by patients with migraine associated with nutritional treatment and focusing attention on nutrients that are consumed during attack periods is an important start point. This approach can help to understand how nutrients affect individuals, to decide whether functional nutrients should be included in the treatment, and to decrease attack frequency. The selection of treatment method after considering all factors is important to achieve a better quality of life. Attention should be paid to lifestyle and behavioral changes that could be used to prevent or delay progression of migraine. Main changes include respecting rules of sleep hygiene, performing relaxation and breathing exercises, obeying recommendations for nutritional arrangements, taking an adequate amount of daily fluid, and maintaining a social life.

\section{Etbics}

Peer-review: Externally peer-reviewed.

\section{Autborship Contributions}

Concept: Ayçıl Özturan, Nevin Şanlıer, Özlem Coskkun, Design: Ayçıl Özturan, Nevin Şanluer, Özlem Coskun, Data Collection or Processing: Ayçıl Özturan, Nevin Şanlier, Özlem Coskun, Analysis or Interpretation: Ayçıl Özturan, Nevin Şanlier, Özlem Coskun, Literature Search: Ayçıl Özturan, Nevin Şanlıer, Özlem Coşkun, Writing: Ayşıl Özturan, Nevin Sanlier, Özlem Coskun.

Conflict of Interest: No conflict of interest was declared by the authors.

Financial Disclosure: The authors declared that this study has received no financial support.

\section{References}

1. Fofi L, Egeo G, Aurilia C, Barbanti P. Migraine prophylaxis: What is new and what we need? Neurol Sci 2011;32(Suppl 1):111-115.

2. Philips P. Mirgaine as a woman's issue-will research and new treatments help? JAMA 1998;280:1975-1976.

3. Lipton RB, Stewart WF, Diamond S, Diamond ML, Reed M. Prevelance and Burden of Migraine in the United States: Data from the American Migraine Study II. Headache 2001;41:646-657.

4. Börü ÜT, Koçer A, Lüleci A, Sur H, Tutkan H, Atlı H. Prevelance and characteristics of migraine in women of reproductive age in İstanbul, Turkey: A Population Based Survey. Tohoku J Exp Med 2005;206:51-59.

5. Taylor RF. Lifestyle changes, dietary restrictions, and nutraceuticals in migraine prevention. Techniques in Regional Anesthesia and Pain Management 2009;13:28-37.

6. The International Classification of Headache Disorders, 3rd edition (beta version). Cephalalgia 2013;33:629-808.
7. The International Classification of Headache Disorders 2nd Edition. Cephalalgia 2004;24(suppl 1):1-160.

8. Rockett FC, Oliveira VR, Castro K, Chaves ML, Perla AS, Perry ID. Dietary aspects of migraine trigger factors. Nutrition Reviews 2012;70:337-356.

9. Millichap GJ, Yee MM. The diet factor in pediatric and adolescent migraine. Pediatr Neurol 2003;28:9-15.

10. Finocchi C, Sivori G. Food as trigger and aggravating factor of migraine NeurolSci 2012;33(Suppl 1):77-80.

11. Sun-Eldestein C, Mauskop A. Foods and supplements in the management of migraine headaches. Clin J Pain 2009;25:446-452.

12. Fukui TP, Gonçalves TRT, Strabelli GC, Lucchino FMN, Matos CF, Santos MPJ, Zukerman E, Zukerman-Guendler V, Mercante JP, Masruha MR, Vieira DS, Peres MFP. Trigger factors in migraine patients. Arq Neuropsiquiatr 2008;66:494-499.

13. Arora H, Rajdeep K. The role of diet in migraine headaches. Delhi Psychiatry Journal 2008;11:69-72.

14. Taylor RF. Nutraceuticals and Headache: The biological basis. American Headache Society 2011;51:484-501.

15. Tan UF, Kalpaklıŏglu AF, Koç SR, Tunçkol M. Migrende IgE Aracılı Allerjinin Rolü. Astım Allerji İmmünoloji 2005;3:10-15.

16. Yaman M, Demirkıran K, Oruç S. Migrende baş ağrısını tetikleyici ve kötüleştirici faktörler. Düzce Tıp Fakültesi Dergisi 2007;9-13.

17. Fava A, Pirritano D, Consoli D, Plastino M, Casalinuovo F, Cristofaro S, Colica C, Ermio C, Bartolo De M, Opipari C, Lanzo R, Consoli A, Bosco D. Chronic migraine in women is associated with insülin resistance: A crosssectional study. European Journal of Neurology 2014;21:267-272.

18. Göksel KB. Menstrüel Migren ve Tedavisi. Türk Nöroloji Dergisi 2008;14:5-14

19. Bigal ME, Kurth T, Santanello N, Buse D, Golden W, Robbins M, Lipton RB. Migraine and cardiovascular disease. Neurology 2010;74:628-635.

20. Bigal EM, Lipton BR. Obesity is a risk factor for transformed migraine but not chronic tension-type headache. Neurology 2006;67:252-257.

21. Dora B, Yılmaz N, Apaydın-Doğan E, Karahasan-Özdemir C, Türkay M. Intergender differences in triggering factors among different subtypes of migraine and tension-type headache. Journal of Neurological Sciences 2010;27;386-394.

22. Scher AI, Stewart WF, Ricci JA, Lipton RB. Factors associated with the onset and remission of chronic daily headache in population-based study. Pain 2003;106:81-89.

23. Keith SW, Wang C, Fontaine KR, Cowan CD, Allison DB. BMI and headache among women: Results from 11 epidemiologic datasets. Obesity (Silver Spring)2008;16:377-383.

24. Brown WJ, Mishra G, Kenardy J, Dobson A. Relationships between body mass index and well-being in young Australian women. International Journal of Obesity 2000;24,1360-1368.

25. Bigal ME, Gironda M, Tepper SJ, Feleppa M, Rapoport AM, Sheftell FD, Lipton RB. Headache prevention outcome and body mass index. Cephalagia 2006;66:545-550.

26. Peterlin BL, Rosso AL, Williams MA, Rosenberg JR, Haythornthwaite JA, Merikangas KR, Gottesman RF, Bond DS, He JP, Zonderman AB. Episodic migraine and obesity and the influence of age, race, and sex. Neurology 2013;81,1314-1321.

27. Robberstad L, Dyb G, Hagen K, Stovner LJ, Holmen TL, Zwart JA. An unfavorable lifestyle and recurrent headaches among adolescents: The HUNT study. Neurology 2010;75:712-717.

28. Peterlin BL, Tietjen EG, Gower BA, Ward NT, Tepper JS, White WL, Dash PD, Hammond ER, Haythornthwaite JA. Ictal adiponectin levels in episodic migraineurs: A randomized pilot trial. Headache 2013;53:474-490.

29. Guldiken B, Guldiken S, Demir M, Turgut N, Tuğrul A. Low leptin levels in migraine: a case control study. Headache 2008;48:1103-1107.

30. Winsvold BS, Sandven I, Hagen K, Linde M, Midthjell K, Zwart JA. Migraine, headache and development of metabolic syndrome: An 11-year follow-up in the Nord-Trondelag Health Study (HUNT). Pain 2013;154:1305-1311.

31. Gozke E, Unal M, Engin H, Gurbuzer N. An observational study on the association between migraines and tension type headaches in patients diagnosed with metabolic syndrome. ISRN Neurology 2012, http://dx.doi. org/10.1155/2013/147065

32. Guldiken B, Guldiken S, Taskiran B, Koc G, Turgut N, Kabayel L, Tugrul A. Migraine in metabolic syndrome. Neurologist 2009;15:55-58. 
33. Panconesi A. Alcohol and migraine: Trigger factor, consumption, mechanisms. J Headache Pain 2008;9:19-27.

34. Wöber-Bingol Ç, Wöber C. Triggers of migraine and tension-type headache. Handbook of Clinical Neurology 2011;97:161-172.

35. Krymchantowski VA, Jevoux CC. Wine and headache. Headache 2014;54:19.

36. Wöber C, Holzhammer J, Zeitlhofer J, Wessely P, Wöber-Bingöl Ç. Trigger factors of migraine and tension-type headache: Experience and knowledge of the patients. J HeadachePain 2006;7:188-195.

37. Marcus DA, Scharff L, Turk D, Gourley LM. A double-blind provocative study chocolate as a trigger of headache. Cephalalgia 1997;17:855-862.

38. D'Andrea G, Terrazzino S, Leon A, Fortin D, Perini F, Granella F, Bussone G. Elevated levels of circulating traceamines in primary headaches. Neurology 2004;62:1701-1705.

39. http://ihs-classification.org/en/02_klassifikation/03_teil2/08.04.01_ substance.html Erişim Tarihi: 30.12.2015
40. Turner PD, Smitherman TA, Penzien BD, Porter AHJ, Martin TV, Houle TT. Nighttime snacking, stress, and migraine activity. Journal of Clinical Neuroscience 2014;21:638-643.

41. Schmitz N, Admiraal-Behloul F, Arkink BE, Kruit MC, Schoonman GG, Ferrari MD, Buchem MA. Attack frequency and disease duration as indicators for brain damage in migraine. Headache 2008;48:1044-1055.

42. Mauskop A, Varughese J. Why all migraine patients should be treated with magnesium. J Neural Transm 2012;119:575-579.

43. Alpay K, M Ertas, Orhan EK, Üstay DK, Lieners C, Baykan B. Diet restriction in migraine, based on IgG against foods: A clinical double-blind, randomised, cross-over trial. Cephalalgia 2010;30:829-837.

44. Aydinlar EI, Dikmen PY, Tiftikci A, Saruc M, Aksu M, Günsoy HG, Tozun N. IgG-Based Elimination Diet in Migraine Plus Irritable Bowel Syndrome. Headache 2013;53:514-525.

45. Airola G, Allais G, Gabellari IC, Rolando S, Mana O, Benedetto C. Nonpharmacological management of migraine during pregnancy. Neurol Sci 2010;31(Suppl 1):S63-65. 